\title{
EX SITU CONSERVATION OF RAFFLESIA PATMA (RAFFLESIACEAE) IN BOGOR BOTANICAL GARDENS (INDONESIA)
}

\author{
Sofi Mursidawati \\ Center for Plant Conservation Botanic Gardens, Indonesia \\ e-mail: sofi001@lipi.go.id \\ Received: 23.03.2017
}

\begin{abstract}
This report presents some methods of cultivation and the inducing of flowering of Rafflesia patma in Bogor Botanical Garden (Indonesia). Many natural habitats of Rafflesia have disappeared through time. Therefore, gardening may contribute to the survival of these species. The grafting method has proven to be successful for the ex situ cultivation of $R$. patma. However, many biological and ecological aspects of this endangered plant are still unknown, while its habitat is disappearing rapidly. This needs a better understanding of the Rafflesia biology to establish appropriate conservation efforts.
\end{abstract}

Key words: Bogor Botanic Gardens, ex situ conservation, flowering, habitat disappearance, Indonesia, Rafflesia

The family Rafflesiaceae Dumort. houses species with the world's largest flowers. As a true parasite they are completely depending on members of the genus Tetrastigma K. Schum., belonging to the grape family (Vitaceae Juss.). They have not any roots or leaves and live unobserved inside woody stems and roots of their hosts except when they form flowers.

Indonesia is one of the diversity centres of the genus Rafflesia R. Br. ex Thomson. Around 15 Rafflesia species are distributed on limited areas in Indonesia, including Java, Sumatra and Kalimantan. The Indonesian Rafflesia species are $R$. arnoldii R.Br., $R$. atjehensis Koord., $R$. bengkuluensis Susatya, Arianto \& MatSalleh, $R$. borneensis Koord., R. ciliata Koord., $R$. gadutensis Meijer, $R$. haseltii Suring., $R$ lawangensis Mat-Salleh, Mahyuni \& Susatya, $R$. meijerii Wiriad. \& Sari, R. micropylora Meijer, $R$. patma Blume, $R$. pricei Meijer, $R$. rochusenii Teijsm. \& Binn., R. tuan-mudae Becc., $R$. witkampii Koord. (Meijer, 1997; Matt Salleh et al., 2001; Nais, 2001; Latiff \& Wong, 2003; Wiriadinata \& Sari, 2010; Susatya, 2011). The occurrence in Indonesia of Rafflesia borneensis, $R$. ciliata and $R$. witkampii need confirmation (Meijer, 1997).

Only R. magnifica is categorised as Critically Endangered by the World Conservation Union (Madulid et al., 2008). However, concern should be given to all the other members of the genus Rafflesia, too, due to their restricted occurrence, extreme fluctuations in the populations' number and the threat of human activities for the species' habitat.

To date, only very few efforts have succeeded in cultivating the species ex situ. The main conservation measures have been efforts of its conservation in situ. The species have complex biological requirements. These are still only partly understood. That is why continuing conservation efforts (e.g. attempts to grow Rafflesia in culture) still remain problematically. Rafflesia species are entirely dependent on their hosts, Tetrastigma spp. (Vitaceae), receiving water and nutrients from it, as the parasitic plants have no photosynthetic capacities (Nais \& Wilcock, 1991). Ultimately, factors affecting Tetrastigma will directly affect Rafflesia. However, the relationships between these two partners are still poorly understood.

Studies of Rafflesia have been carried out since 2004 with emphasis on Rafflesia patma (Fig. 1). Since 2004 attempts to grow R. patma have been conducted in the ex situ conservation area of the Bogor Botanical Gardens. At first, the focus has been placed on biological studies and applicative experiments. Demography, seed biology and anatomy of infected roots were studied with the aim to obtain useful information on biological characteristics of R. patma in the wild. In order to perform ex situ conservation, studies on in vivo and in vitro cultivation and conventional grafting methods were tested. 


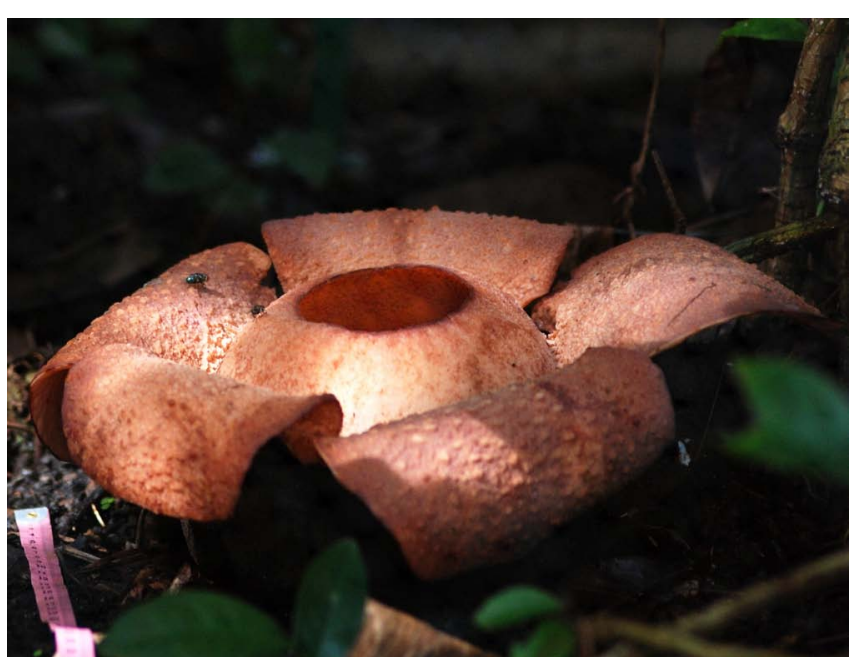

Fig. 1. Rafflesia patma Blume in Bogor Botanical Gardens.

After six year of studies, a $R$. patma flower was firstly registered ex situ. Of the two methods, grafting (cleft and veneer) on the host plant (Tetrastigma scariosum (Blume) Planch) has become successful for the growing of $R$. patma in the Bogor Botanical Garden. There flowering has occurred ten times since 2010 (eight female and two male flowers). The grafting method is a short way to the Rafflesia reproduction. Thus, when mature seeds are difficult to obtain or these are not available, the grafting method has become a successful alternative way for its cultivation (Mursidawati et al., 2015).

The grafting method gives new hope for the establishment of efforts of ex situ conservation of Rafflesia. However, the next step is much more difficult. The unisexual $R$. patma flowers are either male or female. The female flowers could not reach further maturity stage (fruiting) in ex situ cultivation, because there has no pollination been registered. The successful effort to grow $R$. patma in ex situ cultivation is a small step leading towards a larger scenario of a population's establishment. Experience obtained in this initial successful attempt provides the basis for more complex work. It implies carrying out of both human-induced and natural pollination experiments as an effort to establish a viable population.

Studies in conservation biology of Rafflesia still need to be continued as many biological and ecological aspects of these plants are still unknown, while their natural habitats are disappearing rapidly.

\section{References}

Latiff A., Wong M. 2003. A New species of Rafflesia from Peninsular Malaysia. Folia Malaysiana 4(3-4): 135-146.

Madulid D.A., Tandang D.N., Agoo E.M.G. 2008. Rafflesia magnifica. In: The IUCN Red List of Threatened Species 2008: e.T133709A3873727. Downloaded at: 31 March 2017. DOI: 10.2305/IUCN.UK.2008.RLTS. T133709A3873727.en

Matt Salleh K., Susatya A., Hikmat A., Latif A. 2001. Species distribution and conservation of Rafflesia in Indonesia. Dalam Prosiding Seminar Nasional Puspa Langka Indonesia. Bogor: Rafflesia Foundation.

Meijer.W. 1997. Rafflesiaceae. In: Flora Malesiana, series I. Vol. 13. P. 1-42.

MursidawatiS., NgatariN., Irawati I., Cardinal S., Kusumawati R. 2015. Ex situ Conservation of Rafflesia patma Blume (Rafflesiaceae) - an Endangered Emblematic Parasitic Species from Indonesia. Sibbaldia 13: 99-109.

Nais J. 2001. Rafflesia of The World. Sabah Parks and Natural History Publications (Borneo) Sdn Bhd.

Nais J., Wilcock C.C. 1999. The propagation of Rafflesia and its host plant: Prospect for ex situ conservation. Sabah Park Nature Journal 2: 111-120.

Susatya A. 2011. Rafflesia: Pesona Bunga Terbesar di Dunia. Jakarta: Direktorat Kawasan Konservasi dan Bina Hutan Lindung. 104 p. [In Indonesian]

Wiriadinata H., Sari R. 2010. A new species of Rafflesia (Rafflesiaceae) from North Sumatra. Reindwardtia 13(2): 95-100.

\title{
EX SITU COXPAHEHИE RAFFLESIA PATMA (RAFFLESIACEAE) В БОТАНИЧЕСКИХ САДАХ БОГОРА (ИНДОНЕЗИЯ)
}

\section{С. Мурсидавати}

\author{
Центр сохранения растений Ботанических садов, Индонезия \\ e-mail:sofi001@lipi.go.id
}

\begin{abstract}
Данное сообщение представляет некоторые методы культивирования и перевода в фазу цветения Rafflesia patma в Ботаническом саду г. Богор (Индонезия). Выращивание в саду может помочь существованию видов Rafflesia, потому что их места обитания со временем исчезают. Было показано, что метод прививки оказался успешным для культивирования R. patma методом ex situ. Тем не менее, многие биологические и экологические аспекты этого исчезающего растения все еще неизвестны в то время, как его местообитания быстро исчезают. Требуются лучшее понимание биологии Rafflesia для улучшения усилий по его сохранению.
\end{abstract}

Ключевые слова: ex situ сохранение, Rafflesia, Ботанические сады Богора, Индонезия, исчезновение местообитания, цветение 